\title{
THE DYNAMICS OF SOUNDSCAPE CONNECTION WITH ARCHITECTURAL ELEMENTS ON TERAS CIKAPUNDUNG BANDUNG
}

\author{
${ }^{1}$ Livie Tamariska. ${ }^{2}$ Roni Sugiarto, S.T, M.T. \\ ${ }^{1}$ Student in the Bachelor's (S-1) Study Program in Architecture \\ at Parahyangan Catholic University \\ ${ }^{2}$ Senior lecturer in the Bachelor's (S-1) Study Program in Architecture \\ at Parahyangan Catholic University
}

\begin{abstract}
In architecture of public space, the experience of place plays an important role in the making of the good quality of public spaces. The experience of the space is multi-sensory, so architecture should emphasize its attention also on the architectural space approach through auditory experience. The study was conducted to determine the dynamics connection of soundscape experience and Terrace Cikapundung architecture.

The research method is qualitative and descriptive analysis. Quantitative measurements are made to complement the qualitative data. The analysis is done through questionnaire distribution, field observation, analysis, and by relating it with the study of theories about public space architecture, soundscape, sacred sounds, sense of place, intention of architecture, and perception theory.

In Terrace Cikapundung are found quite a lot of natural sounds, which are considered as sounds that improve the quality of the people spatial experience. The natural sounds that are found there are the sound of birds, wind, and water flow. While the dominant voice heard is the sound of motor vehicle, which is considered as disturbing sound for the audiences in particular "man-made zone" (zone that borders the highway). This indicates that there are some architectural elements that have not been able to work optimally, especially the design of bordering element between the site with the main sound source (Jalan Siliwangi). Furthermore, the concave physical topology and the zonation of "man-made zone" and "natural zone" is well designed, based on the variety characterictic of function, location, and order of architectural elements, that will give us the study and example of spatial making and good experience of place.

Through design that concern in the multi-sensory aspects of experience, especially in auditory experience, the experience of space can be felt thoroughly and the quality of a public space can be increased.
\end{abstract}

Key Words: soundscape, architectural element, open public space

\section{DINAMIKA KETERHUBUNGAN SOUNDSCAPE DENGAN ELEMEN ARSITEKTURAL PADA TERAS CIKAPUNDUNG BANDUNG}

\author{
${ }^{1}$ Livie Tamariska. ${ }^{2}$ Roni Sugiarto, S.T, M.T. \\ ${ }^{1}$ Mahasiswa S1 Program Studi Arsitektur Universitas Katolik Parahyangan. \\ ${ }^{2}$ Dosen Pembimbing S1 Program Studi Arsitektur Universitas Katolik Parahyangan
}

\begin{abstract}
Abstrak- Dalam arsitektur taman kota, pengalaman ruang memegang peran yang penting dalam pembentukan kualitas ruang publik. Pengalaman ruang tersebut bersifat multiindera, sehingga arsitektur seyogyanya menekankan perhatiannya juga pada ruang arsitektural melalui pengalaman audial (auditory experience). Penelitian dilakukan untuk mengetahui dinamika keterhubungan pengalaman soundscape terhadap arsitektur pada Teras Cikapundung.

Metode penelitian yang dilakukan adalah secara kualitatif dan analisis deskriptif. Pengukuran kuantitatif dilakukan untuk melengkapi data kualitatif tersebut. Analisa dilakukan melalui hasil pembagian kuesioner,
\end{abstract}

\footnotetext{
${ }^{1}$ Corresponding Author: livietamariska@gmail.com
} 
observasi lapangan, analisis, dan menghubungkannya dengan kajian teori tentang arsitektur ruang luar, soundscape, sacred sounds, sense of place, intention inf architecture, dan teori persepsi.

Pada Teras Cikapundung, ditemukan cukup banyak suara natural yang merupakan suara yang meningkatkan kualitas pengalaman ruang pengunjung, yaitu suara burung, angin, dan arus air. Sedangkan suara yang dominan terdengar yaitu kendaraan dinilai mengganggu pengunjung pada "zona buatan" (zona yang berbatasan dengan jalan raya). Hal ini mengindikasikan adanya elemen arsitektur yang belum dapat bekerja maksimal, yaitu elemen pembatas tapak dengan sumber bising utama yaitu Jalan Siliwangi. Lebih lanjut, bentukan tapak yaitu cekungan dan pengaturan zonasi (buatan/man-made dan zona natural) yang baik berdasarkan kesesuaian fungsi, lokasi, dan pengaturan elemen arsitektural memberikan pembelajaran akan penciptaan dan pengolahan ruang dengan pengalaman ruang yang sesuai.

Melalui perancangan yang memperhatikan aspek pengalaman multi-indera khususnya dalam auditory experience, pengalaman ruang dapat dirasakan secara menyeluruh dan kualitas suatu ruang publik dapat meningkat.

Kata Kunci: soundscape, elemen arsitektural, ruang terbuka publik

\section{PENDAHULUAN}

Pengalaman manusia terhadap ruang dalam arsitektur cenderung dipersepsi lebih dominan melalui apa yang terlihat (visual), sehingga penilaian terhadap ruang seringkali terbatasi hanya pada aspek ruang yang menyangkut domain visual, mengabaikan aspek lainnya. Dimensi-dimensi fisik cenderung lebih diperhatikan, mengesampingkan kenyataan bahwa ruang juga mempunyai karakteristik yang terbentuk melalui pendengaran, perabaan, penciuman dan mempengaruhi bagaimana kita mengalami ruang di dalamnya. Ini menyebabkan pengalaman ruang yang diperoleh menjadi terdegradasi. Untuk itu, penting bagi arsitektur untuk lebih menekankan perhatiannya pada ruang arsitektural melalui pengalaman yang multi-indra, salah satunya yaitu pengalaman audial (auditory experience).

Bunyi sebagai salah satu aspek yang mempunyai potensi memperkaya pengalaman ruang, membuka kemungkinan pengalaman ruang yang berbeda dari yang biasa. Bunyi dapat memberikan gambaran mengenai material, jarak, dan volume. Sehingga sangat disayangkan bahwa aspek bunyi masih sering terabaikan dalam proses perancangan. Hal ini yang menjadi dasar lahirnya konsep soundscape yang pertama kali dicetuskan oleh Schafer (1977). Adapun istilah soundscape dapat didefinisikan sebagai kondisi lingkungan akustik yang dialami dan dipersepsikan oleh pengguna, sesuai dengan konteks waktu, tempat, dan aktivitas.

Berkaitan dengan soundscape tersebut, menjadi isu saat ini yaitu semakin bisingnya kehidupan urban perkotaan sebagai konsekuensi dari meningkatnya intensitas aktivitas manusia, pembangunan infrastruktur, dan kendaraan. Kesibukan dan kebisingan yang seolah tak pernah tidur membawa dampak terhadap meningkatnya tekanan hidup yang kemudian berdampak pada menurunnya kualitas hidup masyarakat. Ketenangan dan kenyamanan audial menjadi hal yang sulit untuk didapatkan di tengah kehidupan perkotaan.

Kehadiran ruang publik seyogyanya mampu menjadi jawaban atas permasalahan tersebut. Upaya dilakukan yaitu merevitalisasi ruang publik yang diharapkan menjadi "oasis" dari kebisingan kota, dan memberikan kesempatan bagi warga kota untuk menghabiskan waktu, relaksasi, dan menghilangkan stres. Namun tentunya hal tersebut hanya dapat dicapai jika ruang publik kota terdesain dengan baik dan memberi pengalaman ruang yang sesuai dengan ekspektasi dan persepsi masyarakat, termasuk dengan memenuhi syarat soundscape yang baik.

Sebagai salah satu ruang publik, Teras Cikapundung didesain sebagai ecotechno riverpark dengan fungsi rekreatif-edukatif. Pendekatan desain bertema sungai tersebut dimaksudkan agar mengedukasi masyarakat melalui pengalaman ruang di sekitar bantaran sungai yang bersih di tengah kota. Teras Cikapundung menjadi sebuah objek yang menarik untuk diamati berkaitan dengan aspek fisik yang memiliki bentuk ruang cekungan, adanya elemen sungai yaitu air yang sekaligus menjadi tema rancangan, pembagian zoning yang 
kontras antara area buatan (man-made) dan natural yang dipisahkan oleh aliran Sungai Cikapundung, batas tapak berupa jalan raya yang padat dan area hutan kota Babakan Siliwangi, dan elemen arsitektural lainnya.

Pembagian zona (menurut pihak perancang) terbagi menjadi area buatan (man-made) dan natural. Zona buatan (man-made) berisi fungsi berupa fungsi komunal ampiteater dan didesain dengan gaya moderen. Adapun area natural terdapat kolam ikan khas Cikapundung dan pendopo-pendopo, dan berbatasan langsung dengan Hutan Kota Babakan Siliwangi yang rimbun.

\section{KAJIAN TEORI}

Setelah dilakukan pendataan, maka dapat diketahui mengenai pengalaman ruang pengunjung di Teras Cikapundung, baik di zona natural maupun zona buatan (man-made). Selain itu diperoleh pula data mengenai suara-suara yang mempengaruhi persepsi pengunjung, dan elemen arsitektural yang membentuknya. Dalam proses analisis digunakan teori-teori yaitu teori ruang terbuka publik, soundscape, intention in architecture, sense of place, dan akustik dalam arsitektur.

\section{METODA PENELITIAN}

Penelitian dilakukan pada empat titik lokasi ruang terbuka. Empat titik fokus penelitian dipilih berdasarkan observasi perbedaan soundscape yang paling kontras dengan mempertimbangkan aspek fisik pembentuk ruang yaitu jalan raya, sungai, dan perbatasan dengan hutan kota, dan perbedaan elevasi sebagai konsekuensi bentuk cekungan.

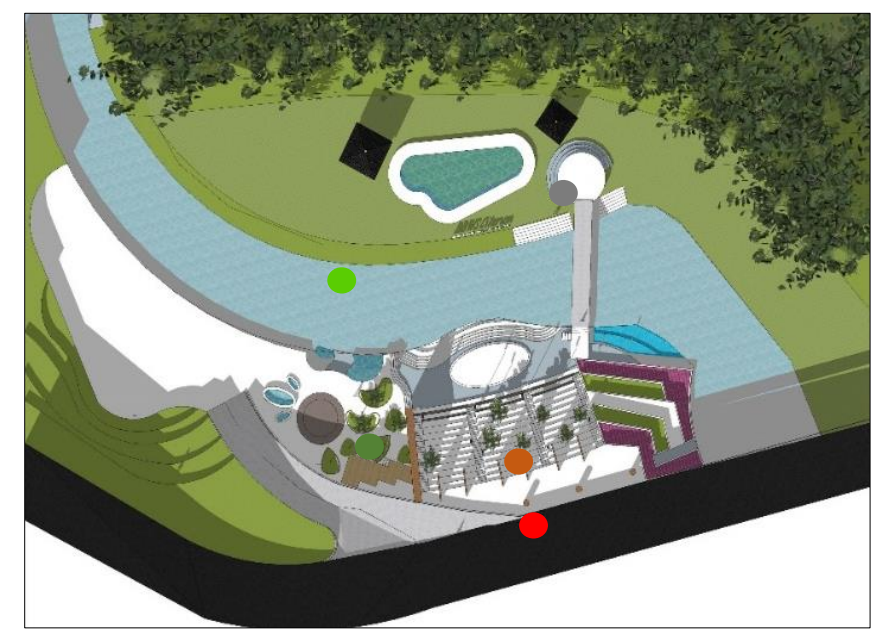

Titik 1 : Zona Urban (pertunjukan air mancur)

Titik 2 : Zona Urban (ampiteater bawah)

Titik 3 : Zona Urban (ampiteater atas)

Titik 4 : Zona Natural (pendopo tepi kolam)

Titik 5 : Zona Natural (Tepi sungai)

Figur 1. Empat Titik Penelitian yang Dipilih Berdasarkan Pusat Aktivitas

\section{ANALISA}

\subsection{PAPARAN DATA PENELITIAN}

\subsubsection{DATA UMUM}

Teras Cikapundung merupakan bagian dari Restorasi Sungai Cikapundung yang merupakan program kerja Balai Besar Wilayah Sungai (BBWS) Citarum. Restorasi dilakukan sebagai upaya untuk melakukan penataan di sepanjang Kawasan Sempadan Sungai 
Cikapundung untuk fungsi Natural (menjaga kualitas air) sekaligus fungsi sosial (wisata dan edukasi).

Teras Cikapundung memiliki satu akses yaitu dari arah Jalan Siliwangi. Jalan Siliwangi merupakan jalan menurun dua arah dengan lebar $10 \mathrm{~m}$ dan ditumbuhi vegetasi di sisi kiri-kanan jalan. Jalan Siliwangi terletak $8 \mathrm{~m}$ lebih tinggi dari Teras Cikapundung. Hingga kini, Teras Cikapundung menjadi kawasan taman kota yang senantiasa aktif dan ramai dikunjungi wisatawan maupun penduduk Bandung, baik saat hari kerja maupun akhir pekan. Selain menikmati keindahan taman dan Sungai Cikapundung, kegiatan rutin di Teras Cikapundung yang dapat dilakukan setiap hari dari pukul 08.00 sampai pukul 20.00 yaitu terapi ikan, wisata air rafting, dan memancing ikan di kolam. Adapun pertunjukan air mancur menari dapat dinikmati setiap harinya pada pukul 16.30 dan 19.30. Pada hari Selasa, Sabtu, dan Minggu pukul 06.30 rutin diadakan senam pagi bersama.

\subsubsection{KONSEP ARSITEKTUR TERAS CIKAPUNDUNG}

Zonasi pada Teras Cikapundung dibagi menjadi zona buatan (man-made) dan zona Natural. Zona Buatan (man-made) berbatasan langsung dengan Jalan Siliwangi, sedangkan zona Natural berbatasan langsung dengan lereng dari Hutan Kota Babakan Siliwangi yang sekaligus menjadi batas/ dinding pelingkup di sisi utara. Sungai menjadi pembatas kedua zona dan memiliki level berbeda dengan dua zona tersebut.

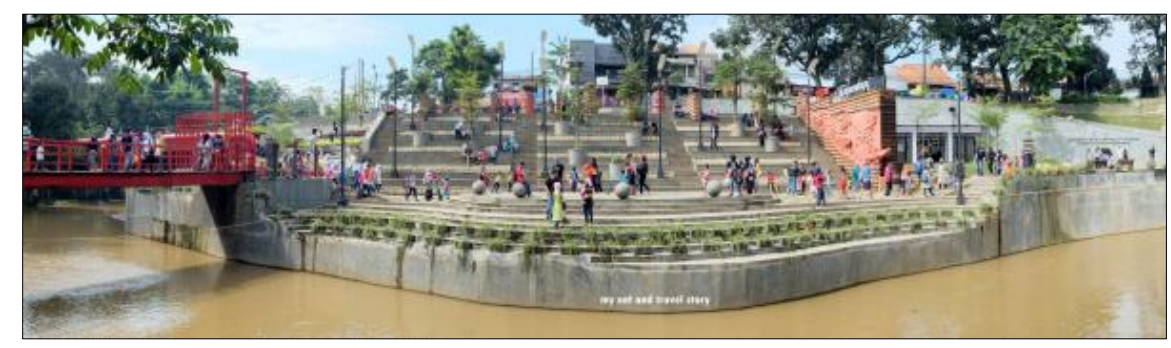

Figur 2. Zona Buatan (man-made)

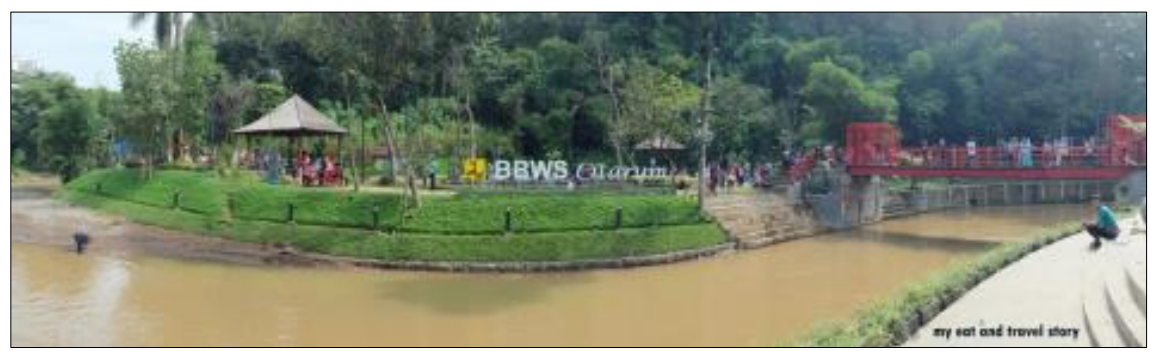

Figur 3. Zona Natural 


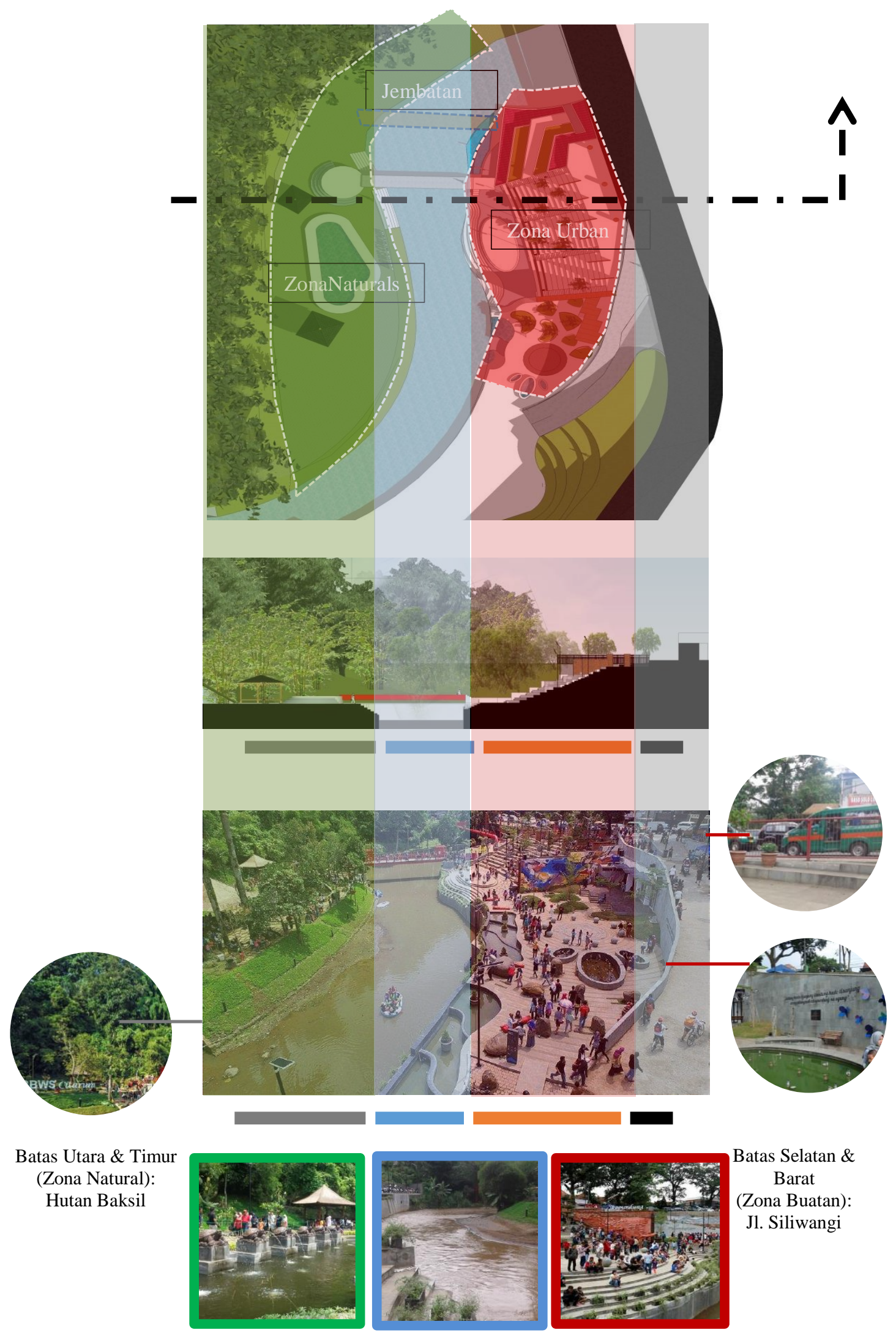

Figur 4. Konsep Zonasi Teras Cikapundung 


\subsubsection{DATA BUNYI TERAS CIKAPUNDUNG}

Penelitian dilakukan ketika hari kerja (Senin dan Selasa 20 \& 28 Februari 2017) dan akhir pekan (Sabtu, 4 Maret 2017) dikarenakan perbedaan aktivitas dan jumlah pengunjung. Selain itu, penelitian dilakukan dengan pembagian 4 range waktu, yaitu pagi (7.00-11.00), siang (11.00-14.00), petang (14.00-17.00), dan sore menjelang malam (17.00-20.00).

Hasil pendataan suara adalah sebagai berikut.

Tabel 1. Rekapitulasi Data Bunyi

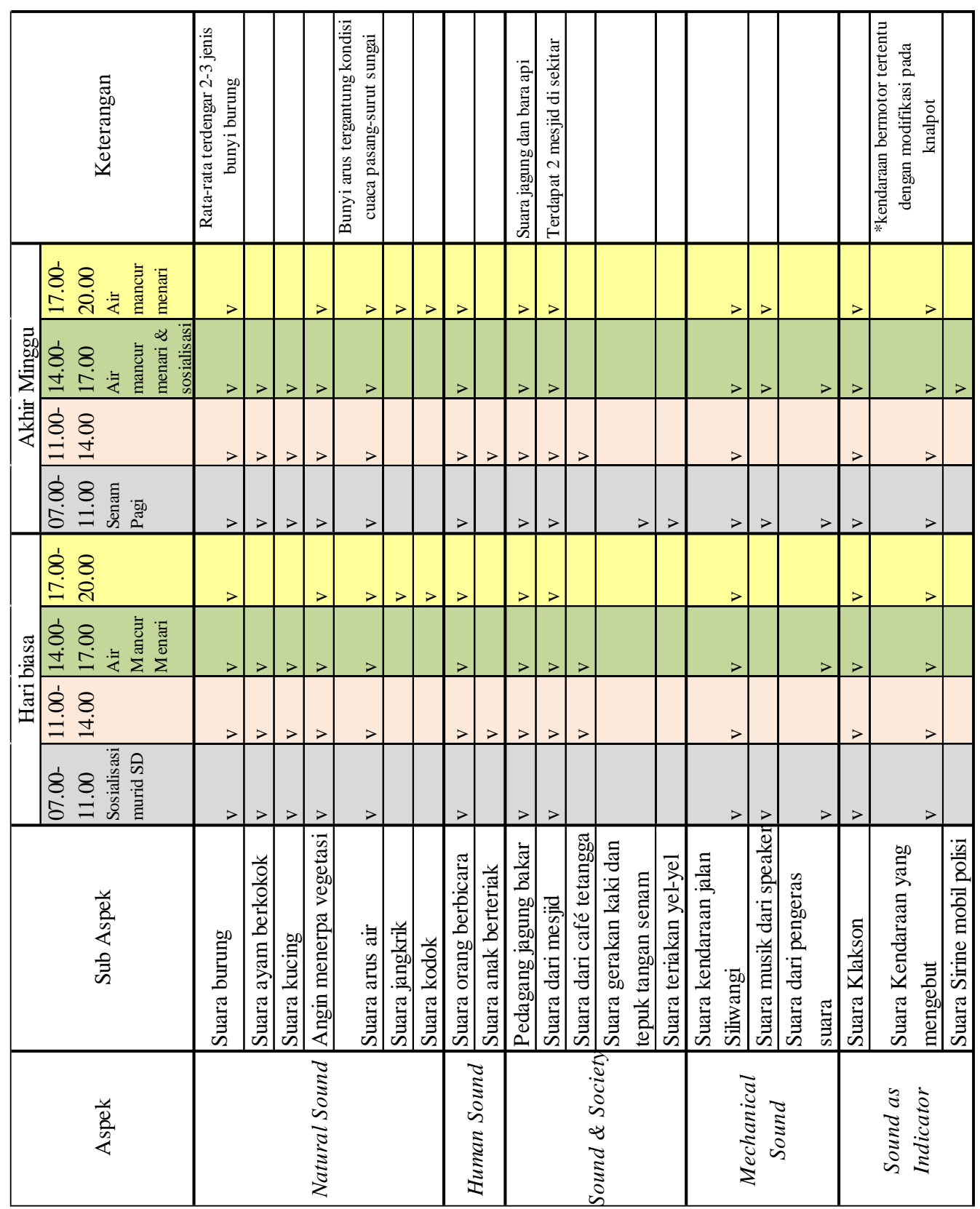

\subsection{KETERKAITAN SOUNDSCAPE DENGAN ELEMEN ARSITEKTURAL} PADA TERAS CIKAPUNDUNG BANDUNG

\subsubsection{HUBUNGAN SOUNDSCAPE DENGAN KAWASAN KOTA BANDUNG}

Selain elemen natural (hutan kota dan sungai) yang kuat, Teras Cikapundung juga tidak terlepas dari karakteristik buatan (man-made) kota dan kebisingan jalan. Sehingga sumber bunyi yang terdengar di Teras Cikapundung cukup beragam dengan karakteristik yang 
bermacam-macam. Berikut ini adalah sumber-sumber suara dari kawasan yang terdengar di dalam Teras Cikapundung.

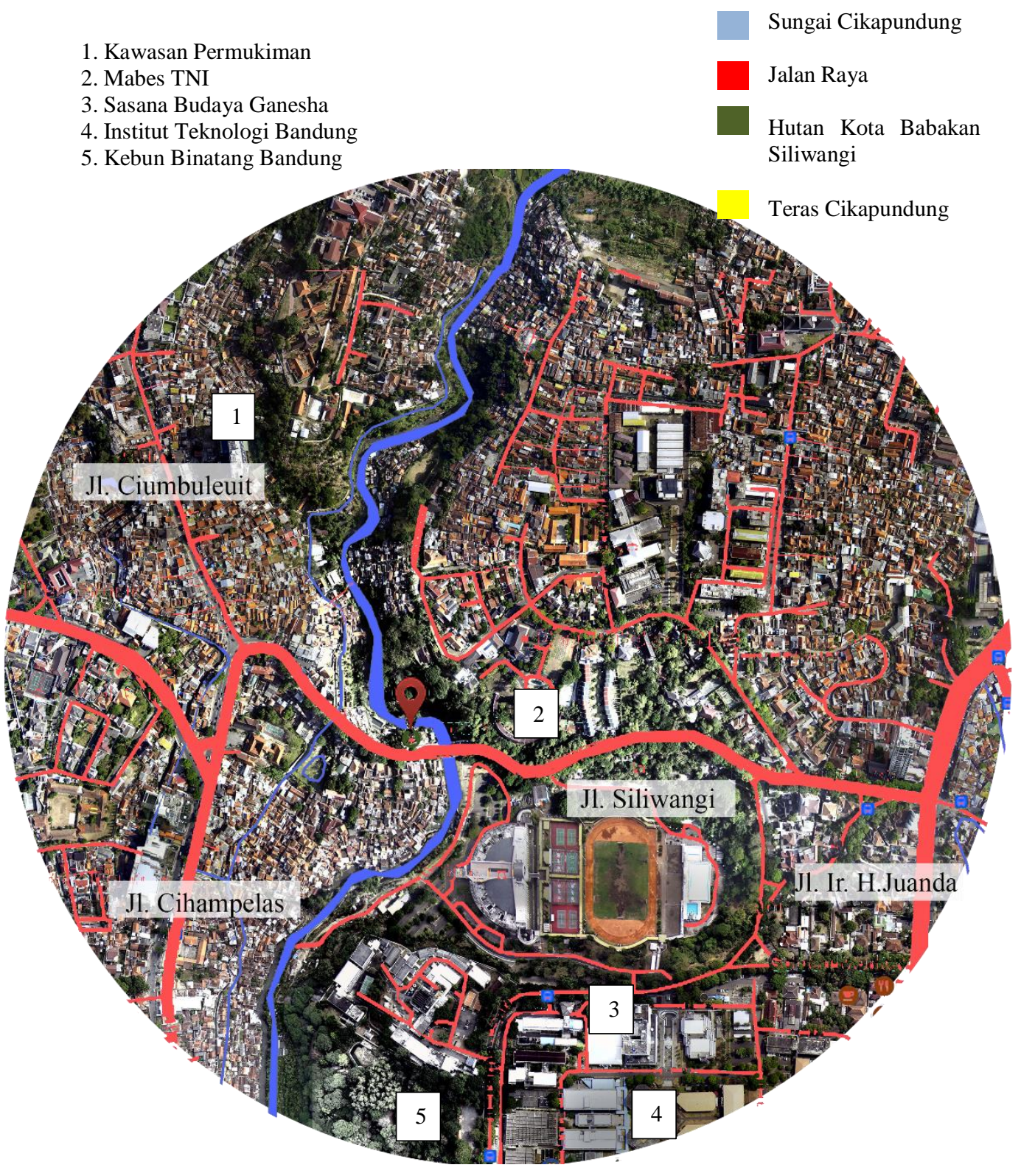

Figur 5. Rupa Bumi dan Fungsi Sekitar Kawasan Sumber: Google Citra 2016 


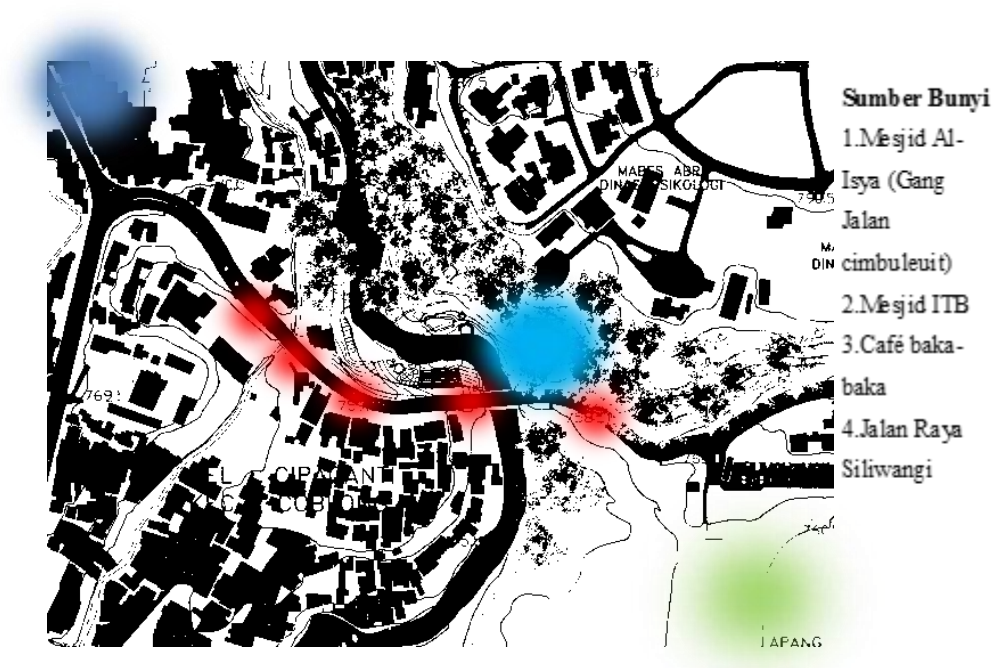

Figur 6. Sumber Bunyi Teras Cikapundung

\subsubsection{HUBUNGAN SOUNDSCAPE DENGAN PENDENGAR}

Hasil pembagian kuesioner menunjukan bahwa suara yang paling terdengar oleh pengunjung yaitu suara kendaraan lewat (dipilih oleh 55\% pengunjung), suara burung (25\%), dan suara manusia berbicara $(10 \%)$. Suara lain yang terdengar adalah suara klakson, suara anak-anak, suara burung, angin menerpa vegetasi, adzan, dan suara arus air. Kendati suara yang dominan adalah suara kendaraan dan diikuti oleh suara manusia dan suara burung, ternyata seluruh responden tetap merasa nyaman dan senang ketika mengunjungi Teras Cikapundung.

Dari hasil wawancara, aspek yang menjadi faktor perasaan nyaman tersebut dikarenakan dapat melakukan aktivitas tanpa terganggu kondisi tertentu, baik itu bising maupun aspek kualitas keamanan dan kebersihan yang buruk. Ketersediaan berbagai fasilitas yang menarik, keindahan pemandangan, dan suasana tenang menjadi faktor-faktor pengunjung menilai Teras Cikapundung sebagai tempat yang menyenangkan untuk melakukan berbagai aktivitas.

Di bawah ini adalah penilaian/ persepsi masing-masing responden di kedua zona tersebut terhadap bunyi tertentu yang mereka dengar saat itu.

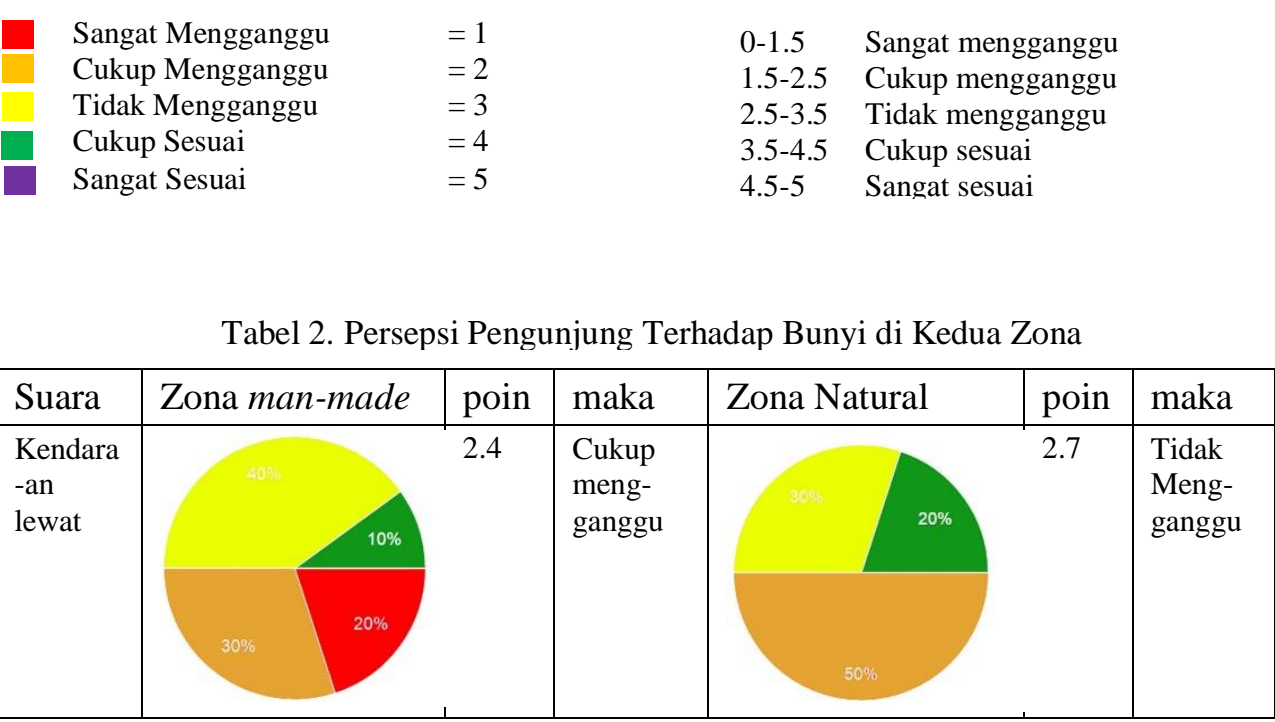


The Dynamics of Soundscape Connection with Architectural Elements on Teras ...

\begin{tabular}{|c|c|c|c|c|}
\hline Klakson & 1.6 & $\begin{array}{l}\text { Cukup } \\
\text { meng- } \\
\text { ganggu }\end{array}$ & 2.1 & $\begin{array}{l}\text { Cukup } \\
\text { Meng- } \\
\text { ganggu }\end{array}$ \\
\hline $\begin{array}{l}\text { Anak- } \\
\text { anak }\end{array}$ & 3 & $\begin{array}{l}\text { Tidak } \\
\text { meng- } \\
\text { ganggu }\end{array}$ & 3.4 & $\begin{array}{l}\text { Tidak } \\
\text { Meng- } \\
\text { ganggu }\end{array}$ \\
\hline Manusia & 3.2 & $\begin{array}{l}\text { Tidak } \\
\text { Meng- } \\
\text { ganggu }\end{array}$ & 3.5 & $\begin{array}{l}\text { Tidak } \\
\text { Meng- } \\
\text { ganggu }\end{array}$ \\
\hline Burung & 4.1 & $\begin{array}{l}\text { Cukup } \\
\text { Sesuai }\end{array}$ & 4.3 & $\begin{array}{l}\text { Cukup } \\
\text { Sesuai }\end{array}$ \\
\hline Angin & 3.8 & $\begin{array}{l}\text { Cukup } \\
\text { Sesuai }\end{array}$ & 4.4 & $\begin{array}{l}\text { Cukup } \\
\text { Sesuai }\end{array}$ \\
\hline Mesjid & 3 & $\begin{array}{l}\text { Tidak } \\
\text { Meng- } \\
\text { ganggu }\end{array}$ & 3.5 & $\begin{array}{l}\text { Cukup } \\
\text { Sesuai }\end{array}$ \\
\hline Air & 3.6 & $\begin{array}{l}\text { Cukup } \\
\text { Sesuai }\end{array}$ & 4.3 & $\begin{array}{l}\text { Cukup } \\
\text { Sesuai }\end{array}$ \\
\hline $\begin{array}{l}\text { Rata- } \\
\text { rata } \\
\text { desibel }\end{array}$ & 62.8 & & $\begin{array}{l}61.6 \\
\mathrm{dBa}\end{array}$ & \\
\hline
\end{tabular}




\begin{tabular}{|c|l|l|l|l|l|l|}
\hline $\begin{array}{c}\text { Rata- } \\
\text { rata } \\
\text { poin }\end{array}$ & 3.13 & $\begin{array}{c}\text { Tidak } \\
\text { Meng- } \\
\text { ganggu }\end{array}$ & & 3.6 & $\begin{array}{c}\text { Cukup } \\
\text { Sesuai }\end{array}$ \\
\hline
\end{tabular}

Hasil pengukuran desibel menunjukan rata-rata tingkat kebisingan sebesar $61.6 \mathrm{dba}$ di zona natural dan 62.8 dba di zona buatan (man-made). Hasil pengukuran tersebut masih di atas standar kenyamanan ruang publik yaitu $50 \mathrm{dBa}$ menurut peraturan dari Kemen Lingkungan Hidup.

Hasil pengukuran secara kuantitatif tersebut sesuai dengan hasil kuesioner persepsi pengunjung di atas, di mana pengunjung di zona man-made lebih banyak mengkategorikan suara yang terdengar sebagai suara yang mengganggu, sehingga dapat disimpulkan bahwa soundscape di zona natural dinilai lebih baik.

\subsubsection{HUBUNGAN SOUNDSCAPE DENGAN ARSITEKTUR TERAS CIKAPUNDUNG}

Elemen tatanan/ setting fisik mencakup elemen horizontal (base plane) dan elemen vertikal (vertical plane). Bentuk dan material dari tatanan fisik tersebut akan berpengaruh terhadap pantulan bunyi yang terjadi dan berdampak pada pengalaman soundscape.

Tabel 3. Analisis Elemen Arsitektural Base Plane

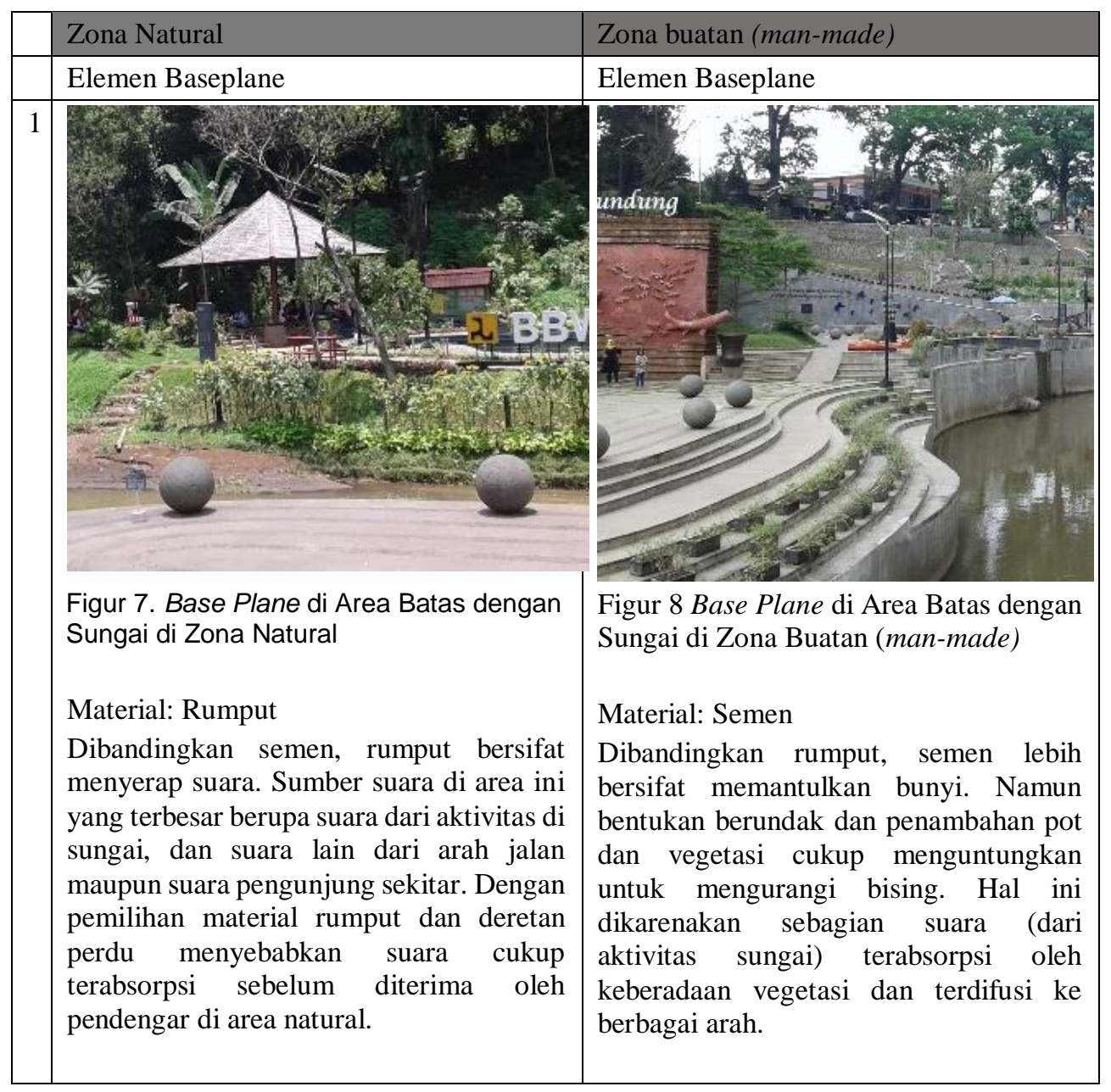




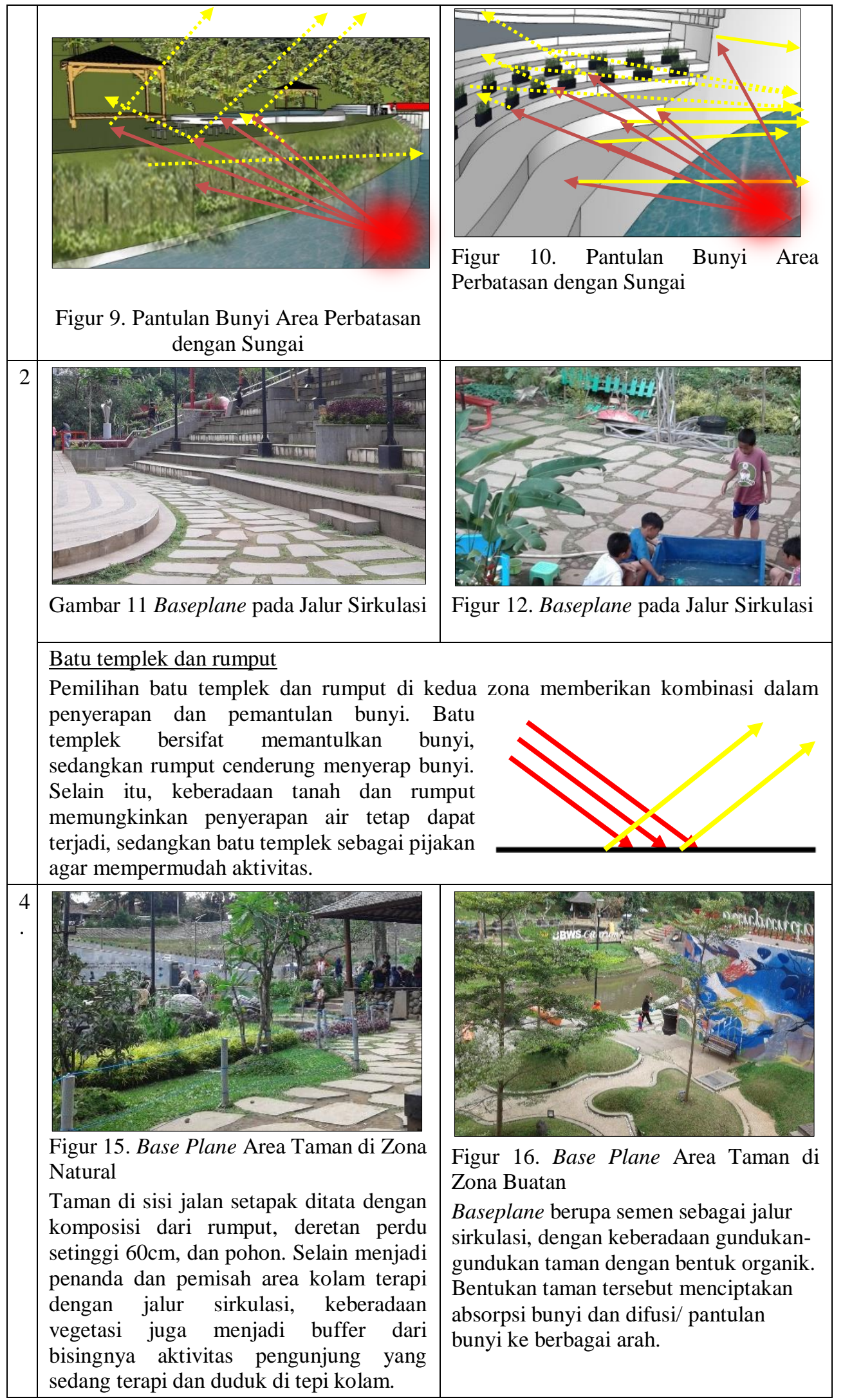

Tabel 4. Analisis Elemen Arsitektural Vertical Plane

\begin{tabular}{|c|c|c|c|}
\hline Zona Natural & & \multicolumn{2}{|c|}{ Zona buatan (man-made) } \\
\hline \multicolumn{4}{|c|}{ Elemen Vertikal } \\
\hline Foto & Analisis & Foto & Analisis \\
\hline
\end{tabular}




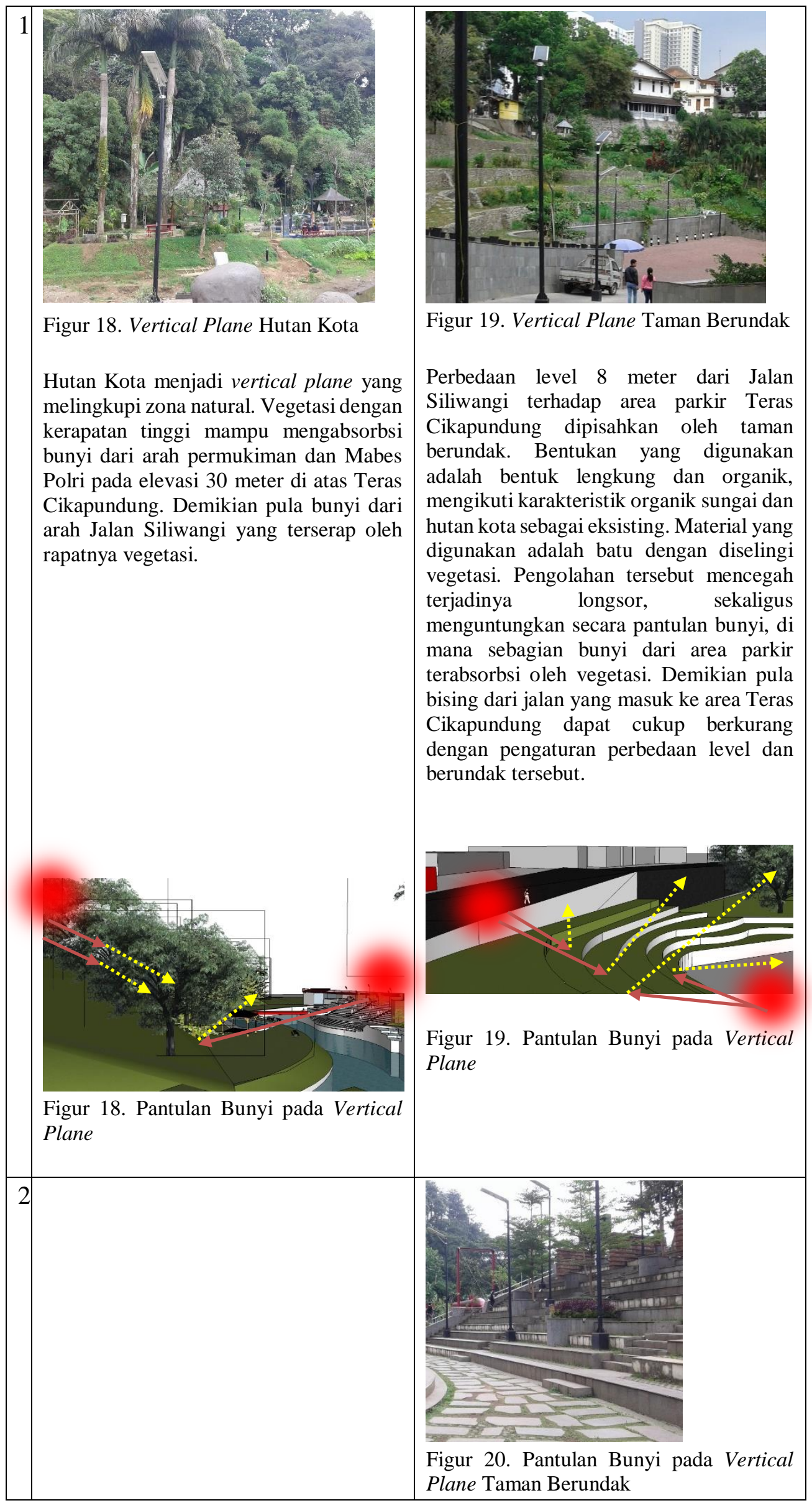




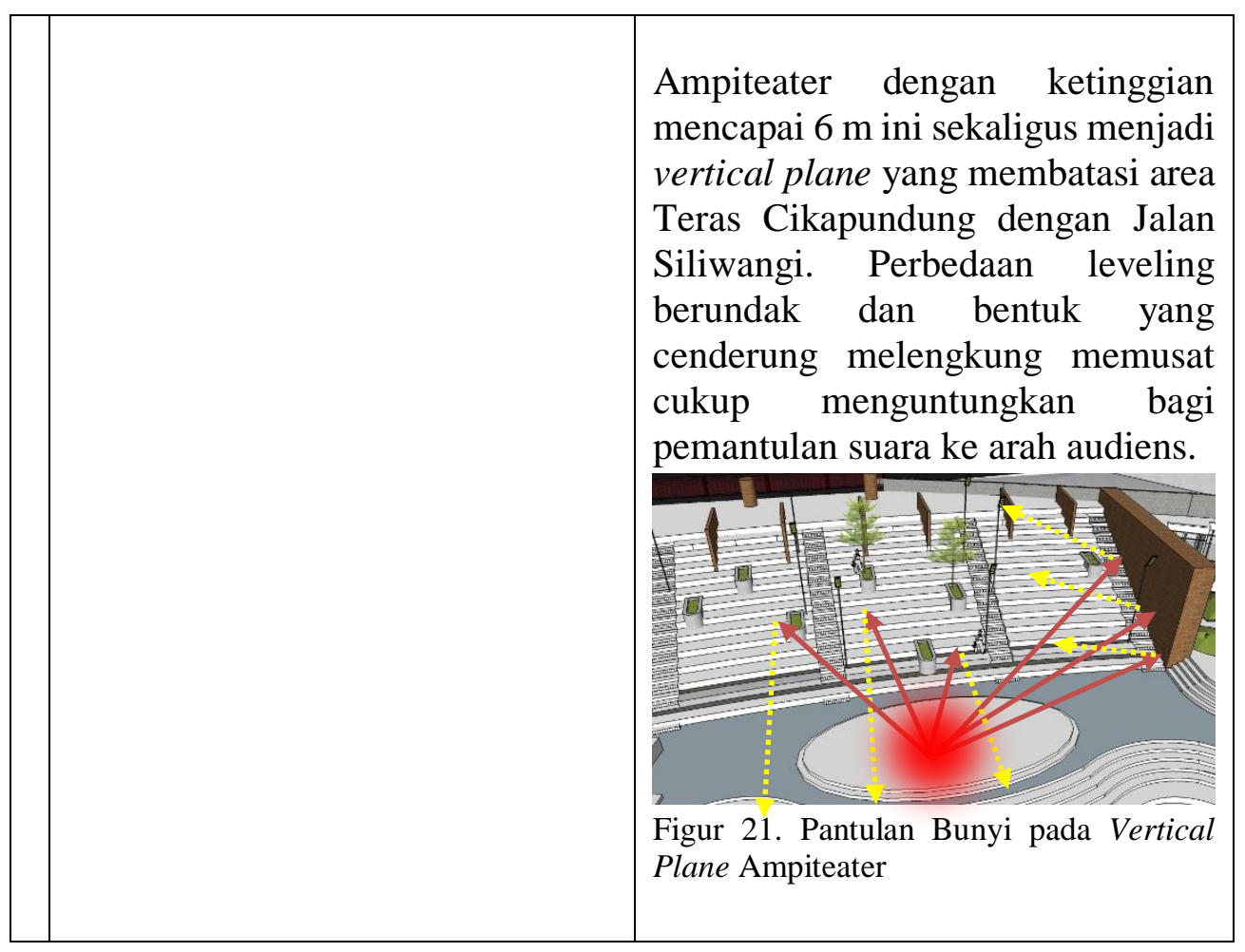

Pada bagian sebelumnya telah dikaji bagaimana kinerja bentuk, tatanan, dan elemen arsitektural Teras Cikapundung terhadap bunyi-bunyi yang ada di Teras Cikapundung. Lebih lanjut kondisi audial Teras Cikapundung tersebut dilihat kesesuaiannya dengan persepsi manusia berdasarkan hasil kuesioner. Apabila suara dikategorikan mengganggu maka dibutuhkan rancangan khusus yang mengurangi sumber bunyi tersebut. Rancangan tersebut dirancang baik dengan pengaturan zoning, bentuk \& karakter fisik, maupun pemilihan elemen arsitektural (material, dimensi, dan bentuk).

Sesuai dengan teori Building Task oleh Schulz (1997), elemen arsitektural yang memisahkan sumber bising tersebut yaitu elemen barrier. Suara yang cukup mengganggu membutuhkan elemen yang mengubah suara tersebut menjadi suara indirect (tidak langsung), berupa filter. Sedangkan suara yang tidak mengganggu membutuhkan elemen connector ataupun yang bersifat switch (regulating) sesuai kondisi bising dan kebutuhan ruang. Di samping itu, ada pula suara yang justru dinilai sesuai dan menambah kualitas ruang. Suara seperti itu dapat dimaksimalkan dalam perancangan arsitektur yang mengarahkan dan memperkuat bunyi dan menciptakan pengalaman soundscape Teras Cikapundung.

Secara zonasi, hasil analisis menunjukkan bahwa baik aktivitas individual maupun komunal tersebar di kedua zona, namun dengan kegiatan komunal lebih banyak terdapat di zona buatan/ man-made, sedangkan tatanan arsitektural yang memancing aktivitas dengan sifat individual banyak ditemukan di zona natural.

Hal ini sangat menguntungkan bagi pengalaman soundscape di kedua zona, di mana aktivitas individual lebih membutuhkan pengalaman ruang yang kontemplatif dan terwujud pada zonasi natural dengan suasana alam dan lebih jauh dari posisi bising kendaraan dari jalan. Sedangkan aktivitas komunal menurut Lang (1987) lebih bersifat memberikan kesempatan kepada orang untuk bertemu bersama-sama dalam sebuah aktivitas, diskusi, atau topik umum, dan tidak menuntut pengalaman soundscape yang kontemplatif sehingga posisi yang berdekatan dengan gerbang masuk dan jalan umum tidak mengganggu kenyamanan dalam aktivitas. Selain itu sebuah ruang terbuka publik akan menarik jika terdapat aktivitas dan orang dapat menyaksikannya. 
Secara kesesuaian bentuk dan karakter fisik Teras Cikapundung pada zona buatan (man-made), sumber suara utama yaitu Jalan Siliwangi berupa kendaraan, (kategori: cukup mengganggu), dan klakson (kategori: cukup mengganggu)

Tabel 5. Bentuk dan Karakter Fisik Arsitektur pada Zona Buatan

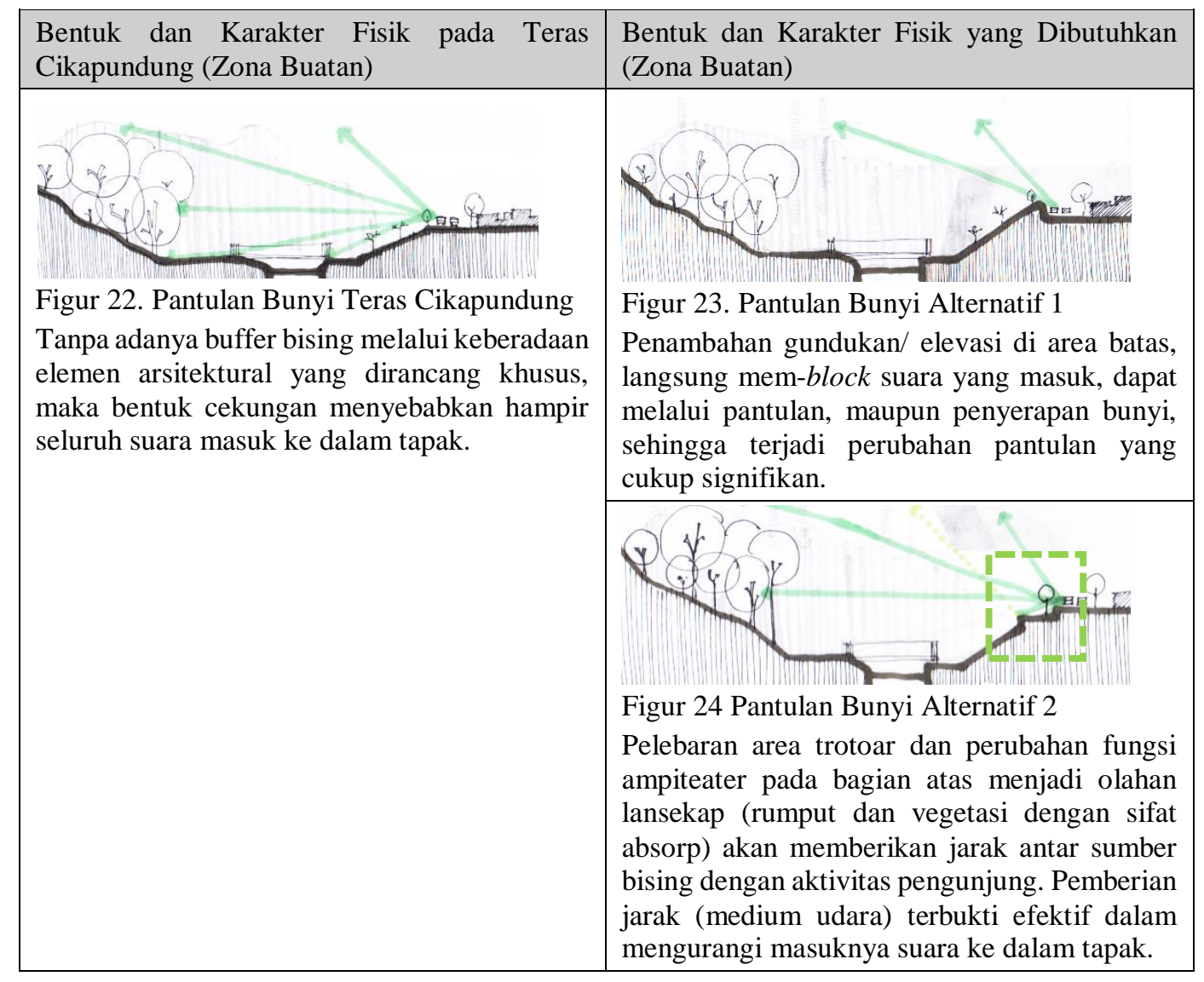

Sedangkan pada zona natural dengan sumber suara utama Jalan Siliwangi, persepsi pengunjung terhadap suara klakson yaitu cukup mengganggu, sedangkan kendaraan masuk dalam kategori tidak mengganggu.

Tabel 6. Bentuk dan Karakter Fisik Arsitektur pada Zona Natural

\begin{tabular}{|c|c|}
\hline $\begin{array}{l}\text { Bentuk dan Karakter Fisik pada Teras } \\
\text { Cikapundung (Zona Natural) }\end{array}$ & $\begin{array}{l}\text { Bentuk dan Karakter Fisik yang Dibutuhkan } \\
\text { (Zona Natural) }\end{array}$ \\
\hline & \\
\hline $\begin{array}{l}\text { Figur } 25 \text { Pantulan Bunyi dari Jalan yang Masuk } \\
\text { ke Dalam Zona Natural }\end{array}$ & $\begin{array}{l}\text { Figur } 26 \text { Pantulan Bunyi dari Jalan yang Masuk } \\
\text { ke Zona Natural dengan Filter }\end{array}$ \\
\hline $\begin{array}{l}\text { Bentuk cekungan menyebabkan hampir } \\
\text { seluruh suara masuk ke dalam tapak. Namun } \\
\text { ternyata pada zona natural, sebagian besar } \\
\text { pengunjung merasa bahwa suara kendaraan }\end{array}$ & $\begin{array}{l}\text { Kendati suara kendaraan dinilai tidak } \\
\text { mengganggu, namun suara klakson masih } \\
\text { cukup terdengar dan cukup mengganggu. Maka }\end{array}$ \\
\hline
\end{tabular}


merupakan suara yang tidak mengganggu. Hal ini dikarenakan jarak yang sudah lebih jauh (dibandingkan zona buatan) dengan sumber bising, dan keberadaan elemen arsitektur lainnya yang sudah memantulkan dan menyerap bunyi. Hanya saja suara klakson dengan intensitas dan bising lebih besar masih terdengar jelas dan dinilai cukup mengganggu.

\section{KESIMPULAN}

Dinamika keterhubungan soundscape dengan elemen arsitektural Teras Cikapundung dikaji secara terintegrasi melalui studi pengalaman soundscape pada Teras Cikapundung yang dipengaruhi aspek kawasan dan persepsi pengunjung.

Karakteristik kawasan dan fungsi sekitar Teras Cikapundung serta keberadaan Anak Sungai Cikapundung menciptakan pengalaman multi-indera yang berbeda di tengah fenomena kota dan bising kota pada khususnya. Selain elemen natural (hutan kota dan sungai) yang kuat, Teras Cikapundung juga tidak terlepas dari karakteristik buatan (man-made) kota dan pengaruh kebisingan jalan, sehingga sumber bunyi yang terdengar di Teras Cikapundung kaya akan kedua elemen kontras yang sama kuat tersebut.

Pengunjung Teras Cikapundung menilai pengalaman soundscape cukup nyaman dalam mendukung aktivitas pengunjung taman. Suasana yang diarasakan melalui pengalaman multiindera pengunjung adalah perasaan tenang, aman, puas, nyaman, kedekatan dengan alam, dan kesenangan. Adapun suasana tidak sepenuhnya memenuhi perasaan solitude (kesendirian) dan tranquility.

Pada zona buatan yang berdekatan dengan jalan, ditemukan lebih banyak suara yang dinilai cukup mengganggu, yaitu klakson dan suara kendaraan bermotor. Sedangkan pada zona natural, suara kendaraan bermotor dianggap tidak mengganggu. Selain itu di zona natural ditemui lebih banyak suara yang diinginkan dan dinilai sesuai, yaitu suara burung, angin, adzan, dan arus air. Sebagai tempat berlangsungnya berbagai pertunjukan, soundscape Teras Cikapundung pada zona buatan/ man-made dinilai memberikan soundscape yang baik dan sesuai.

Dalam keterkaitan soundscape dengan arsitektur Teras Cikapundung itu sendiri, sebagian besar elemen sudah bekerja dengan maksimal sesuai dengan kebutuhan akan suasana yang diinginkan melalui penempatan vegetasi, pemilihan material rumput, dan taman berundak. Sedangkan suara yang cukup mengganggu yaitu suara kendaraan dan klakson membutuhkan elemen arsitektural yang lebih mem-buffer bunyi. Area batas tapak dengan Jalan Siliwangi kini hanya dipisahkan dengan pagar besi yang berbentuk grill dengan transparansi sangat tinggi (kerapatan $15 \mathrm{~cm}$ dan tinggi $1.2 \mathrm{~m}$ ). Demikian pula dengan ketiadaan vegetasi yang bersifat mem-filter suara dari arah jalan menyebabkan masuknya suara dari arah jalan ke dalam Teras Cikapundung. 
Dalam pengaturan zonasi dan penciptaan ruang yang membentuk aktivitas, Teras Cikapundung memiliki konsep yang kuat dan tercermin dengan baik dalam perancangan, di mana zona buatan lebih dikhususkan untuk kegiatan dengan sifat komunal, dan zona natural untuk kegiatan dengan sifat lebih individual. Hal ini sangat menguntungkan dan berpengaruh baik bagi soundscape, mengingat bahwa soundscape bergerak dalam ranah persepsi dengan nilai kontekstualitas yang tinggi, di mana ekpektasi, persepsi, dan preferensi pengunjung menentukan kualitas soundscape itu sendiri.

Dalam peran elemen arsitektur Teras Cikapundung terhadap optimasi suara yang diinginkan dan minimalisasi suara yang kurang diinginkan, dibutuhkan lebih banyak elemen yang berfungsi melakukan filterisasi bunyi. Elemen tersebut dapat berupa penambahan vegetasi, penambahan material absorbtif pada area batas dengan jalan, maupun pegaturan jarak antara sumber bising dengan pusat aktivitas. Untuk mengoptimalkan suara yang diinginkan dapat dilakukan dengan penambahan vegetasi yang mendatangkan burung dan gemerisik angin, maupun penambahan suara gemericik air. Adapun bentuk cekungan efektif dalam menciptakan surrounding soundscape, dengan syarat penanganan khusus sumber bising dari jalan.

Keterhubungan soundscape dengan elemen arsitektural Teras Cikapundung baik bentuk dan tatanan fisik, karakteristik material dan prosporsi, serta zonasi cukup mendukung pengadaan soundscape yang diinginkan. Sementara beberapa titik khususnya pada perbatasan taman dengan Jalan Siliwangi sebagai sumber bising kendaraan (suara yang mengganggu) masih membutuhkan penanganan bising yang lebih optimal.

\section{DAFTAR PUSAKA}

Ashihara, Yoshinobu. (1981). Exterior Design in Architecture. New York: Van Nostrand Reinhold Company.

Brown, A. L., Kang, J., and Gjestland, T. (2011) Towards some standardization in assessing soundscape preference, Applied Acoustics. Queensland: Griffith University.

Francis D.K. Ching. (2007). Arsitektur: Bentuk, Ruang, dan Tatanan. Jakarta: Erlangga.

Lynch, Kevin. (1981). The Image of the Cities. Massachusetts: MIT Press.

Nakagawa, Shin. (2000). Musik dan Kosmos: Sebuah Pengantar Etnomusikologi. Jakarta: Yayasan Obor Indonesia.

Norberg, Christian. (1997). Intentions in Architecture. Massachusetts: MIT Press.

Barker, R.G. (1968). Ecological Psycology: Concept and Methods for Studying the Environment of Human Behavior. Standford: Standford University Press.

Rasmussen, Steen Eiler (1959). Experiencing Architecture. United State RM, Schafer (1977). The tuning of the world. New York: Alfred A. Knopf

Tuan, Yi-Fu (1977). Space and Place: The Perspective of Experience, Minneapolis: University of Minnesota Press

Toha, Miftah. (2003). Perilaku Organisasi Konsep Dasar dan Aplikasinya. Jakarta: Grafindo Persada.Ching, Francis D.K. (2007). Arsitektur: Bentuk, Ruang, dan Tatanan. Jakarta: Erlangga 